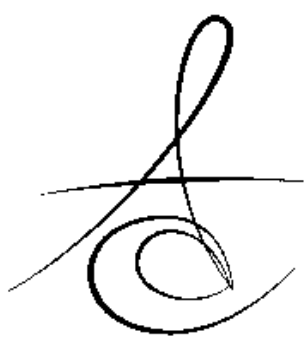

Makale Kodu/Article code: 1624

Makale Gönderilme tarihi; 10.04 .2014

Kabul Tarihi: 20.06 .2014

\section{ORAL HEALTH DURING PREGNANCY AND THE CLINIC APPEARANCE OF PREGNANCY TUMOR (Case Report)}

\section{HAMİLELİKTE AĞIZ SAĞLIĞI VE HAMİLELİK TÜMÖRÜNÜN KLİNİK GÖRÜNÜMÜ (Vaka Sunumu)}

Dr. Gülser KILINÇ

Dt. Hakan KOCA

\section{ABSTRACT}

The aim of this case report is to introduce pregnancy tumors and to emphasize the importance of oral health during pregnancy. Pregnant patient within 34th week of her pregnancy applied our clinic for tuberance and bleeding problems in her gingiva. In her oral examination she was diagnosed with pregnancy tumor. Oral hygiene education was taught to the patient and appropriate dental treatment was made. Bad oral hygiene and increased hormanal levels have an important role in the etiology of pregnancy tumor. It is imported that gynecologist direct their pregnant patients to the dentists and have the appropriate treatment.

Keywords: Pregnancy, pregnancy tumor, oral health.

\section{Background}

Oral changes during pregnancy are occurred dependent on the hormonal changes within this period. Hormonal changes with increased estrogen and progesteron are characterized in the pregnancy. Estrogen and progesteron are dramatically increased at the end of the third trimester. Therefore, the effect on the periodonsium is also increased by hormonal changes ${ }^{1-3}$. Increased hormonal changes during pregnancy may result in inflammation in the gingiva. The so called "pregnancy gingivity" can be observed with erythema, protuberance and bleeding in pregnants ${ }^{4}$. Pregnancy gingivity is not associated with the pregnancy but it can be an increased response against local factors. If an intensive oral care and dental scaling for pregnancy gingivitis diagnosed

\section{ÖZET}

$\mathrm{Bu}$ olgu sunumunun amacı hamilelik tümörünü tanıtmak ve hamilelikte ağız diş sağlığının önemini vurgulamaktır. Hamileliğin 34. haftasında olan hasta, dişetinde şişlik ve kanama şikayetiyle diş kliniğine başvurdu. Yapılan oral muayenesinde gebelik tümörü tanısı konuldu. Hastaya oral hijyen eğitimi verilerek gerekli dental tedaviler yapıldı. Kötü ağız hijyeni ve hormonal seviyenin artması hamilelik tümörünün etiyolojisinde önemli rol oynar. Kadın doğum hekimlerinin hastalarını diş hekimine yönlendirmeli ve uygun dental tedaviler yapılmalıdır.

Anahtar kelimeler: Hamile, hamilelik tümörü, ağız sağlığı

patient are not applied, the disease status can be progressed and have a peak at the end of the third trimester ${ }^{5}$. Professional prophylaxy, oral hygiene and expert consultancy can decrease the frequency and levels of this disease ${ }^{6}$. Many published papers indicate the relationship between bacteria observed in periodontal diseases and low birth weight and premature birth ${ }^{7-9}$. Dental prophlaxy and scaling can be easily applied in each trimesters of normal pregnancy $^{10}$.

Piyogenic granulomas named pregnancy tumors or granüloma gravidarum are observed during pregnancy based on edema in gingivae. Pregnancy tumors are similar to the bening hyperplastic lesions of the gingiva. The most important difference of pregnancy tumor compared to pyogenic granülom is

*Dokuz Eylül University, Health Center, Department of Dentistry 
that it appears during pregnancy and its recession is generally observed after pregnancy since hormonal changes are disappeared ${ }^{4,11,12}$. This disorder was first identified by Pitcarin in $1818{ }^{13}$. The term "pyogenic granuloma" was also identified by Hartzell in $1904^{14}$.

While the prevalance of gingivitis in the pregnants is $35-100 \%$, it is $0.02-5 \%$ for pregnancy tumors $^{1-3,11}$. Pregnancy tumors are generally observed in the second trimester. Gingiva is effected in most cases. Tongue, lips, buccal mucosa and palatina are less effected compared to gingiva? ${ }^{2}$.

Pregnancy tumors are very sensitive to irritations and they grow very fast, easly bleed can be seen in hyperplastic and nodular forms. The color of tumor can be light pink, purple, red and dark blue. It might have a stem or not ${ }^{1,2}$. This disease does not affect the bone tissue but in some cases mild bone resorption can be appeared in radiography ${ }^{14,15}$.

Generally, it is not treated until pregnancy is ended however if it's painful and have excess bleeding and uncomfortable the patient, it can be surgically removed ${ }^{1,2,4,5,14,15}$. This paper presents a case diagnosed with pregnancy tumor that was followed by our center.

\section{CASE REPORT}

A 29 years old pregnant patient within 34th week of her pregnancy applied our center for tuberance and bleeding problems in her gingiva. According to information provided by the patient, it is her third pregnancy and she didn't have such problems during her previous two pregnancies. In the oral examination of the non smoking patient who brushes her teeht twice a day, a pinkish red coloured painless lesion that was attached to the gingiva approximately $1-1,5$ centimeters in diameter, starting from the interdental papilla and leading to the lingual sulcus was observed (Fig. 1). The patient stated that she didn't have problems of chewing and speaking related to this lesion. There was no caries in this area. The patient had three composite fillings in the left and right maxillary first molars and mandibular right firt molar

Bacterial plaque and tartars were observed on the surfaces of the teeth. Plaques and tartars around the lesion, which caused irritation, was removed and topical floride was applied (1.23\% phosphate floride).
The patient used $0.12 \%$ chlorhexidine gluconate and $0.15 \%$ benzidamine hydrochloride twice a day for a week. The patient was taught Oral hygiene education. The patient did not want any operation such as biopsy. Since the patient had no problems for speech and chewing and was also within her third trimester, no operation was also considered by dentists. She was regularly controlled up to last two weeks to birth and no significant growth of the tumor was observed (Fig. 2). Informed consent was taken from the patient.

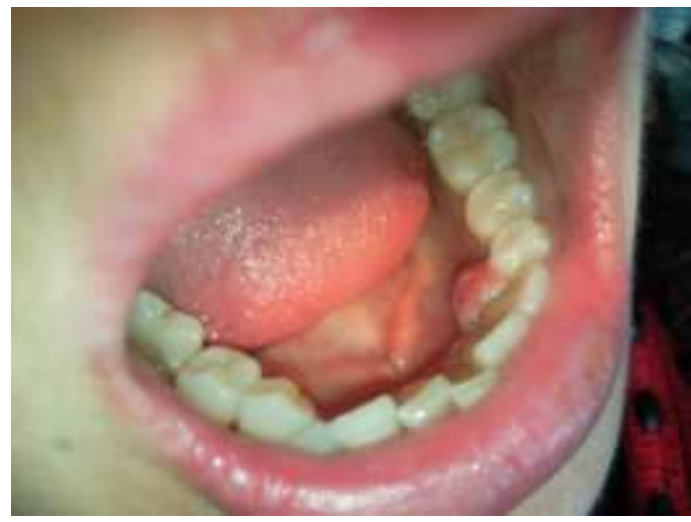

Figure 1. Patient's first clinical view.

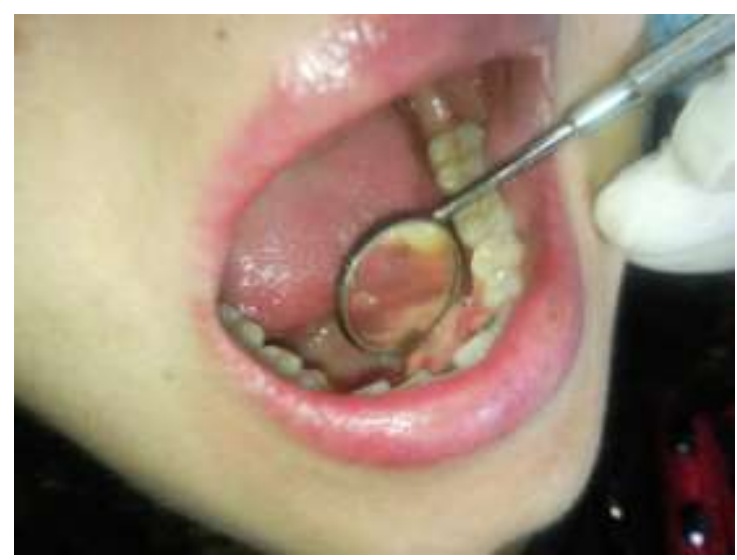

Figure 2. Clinical view 2 week before birth.

\section{DISCUSSION AND CONCLUSION}

Pyogenic granuloma is a benign soft tissue tumor of the mucous membrane and skin occurring in response to a variety of stimuli such as traumatic injury, local irritation or hormonal factors. It can occur

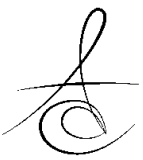


on the lips, tongue, palatal and buccal mucosa in the oral cavity; but commonly found in gingiva ${ }^{16}$.

Pregnancy tumors mostly develop in the first trimester and continue to grow rapidly. Dental plaques, tartar and trauma stimulate the growth of the tumors ${ }^{3}$. Although pregnancy tumors and also pyogenic granuloma are histopathologically considered as same lesions, their therapy protocols show differences. In pregnancy tumors, the increased hormons return their normal ranges and tumor disappaers spontaneously after pregnancy. Pregnancy tumors are generally observed after first trimester $15,17,18$. Many published case studies have been reported on the observation of pregnancy tumors show that it can be seen in the third trimester likewise $2,3,19$. The relationship between sex hormones and gingivitis in pregnants were reported in the literature.

In addition to this, increased gingivitis is associated with the increased progesteron levels in pregnants. It is known that increased progesteron level causes diletasyon in gingiva causing incrase in permiability and level of exudate ${ }^{20-22}$. Increased Provetella intermedia and Porphyromonas gingivalis are reperted during pregnancy ${ }^{1,20,21}$.

For constructing therapy protocol, pregnancy should be taken into consideration. An expectant manner is followed but if the lesion causes bleeding, chewing disorders and does not recess after birth surgical treatment is indicated ${ }^{15,19}$.

Operation during pregnancy is not a preferred therapy method since it shows recurrency. If there is excess bleeding an chewing disorders that disturb patients comfort and daily life surgical tretment can be taken into concideration as shown in some studies $2,17,19$. In over study we didn't consider surgical treatment because the patient stated that she did not have the complaints that we mentioned above.

However, the treatment for the cases with serious bleeding is really difficult. Therapy method is dependent on the clinical status of the case. Although providing of oral hygiene, local tight compressions and local anti-bleeding drugs can be sufficient in mild bleedings, blood transfusion can also be needed for cases with serious bleedings ${ }^{22}$.

Estrogen and progesteron hormons effect the peridontal tissues in different ways in pregnancy ${ }^{21}$. Pregnancy tumors, which can cause seriuos complication during pregnancy should be diagnosed by gyneocologists correctly and the understanding of the symptoms and application of the right therapy protocols by the gyneocologists are of great importance in the therapy of pregnancy tumors. Orientation of the patient with pregnancy tumors to the dentists and providing oral hygiene education are also important parameters in the progress of the disease during pregnancy period.

\section{REFERENCES}

1. Güncü G, Tözüm TF. The effect of estrogen, progesteron and testosterone on periodontal tissues. GÜ Dişhek Fak Derg. 2005; 22: 121-7.

2. Lindenmuller $\mathrm{IH}$, Noll $\mathrm{P}$, Mameghani $\mathrm{T}$, Walter $\mathrm{C}$. $\mathrm{CO} 2$ laser-assisted treatment of a giant pyogenic granuloma of the gingiva. Int $\mathrm{J}$ Dent Hygiene 2010; 8: 249-52.

3. Silva-Sousa YTC, Coelho CMPC, Brentegani LG, Vieria MCSO, Oliviera ML. Clinical and histological evaluation of granuloma gravidarum: case report. Braz Dent J 2000; 11: 135-9.

4. Shlomi B, Orbit OB, Moshe O, Eli EM, Micha P, Gonen O. Common oral manifestations during pregnancy: a review. Obstetrical \& Gynecological Survey 2003; 58: 624-8.

5. Silk HJ, Douglass AB, Douglass JM, Silk L. Oral health during pregnancy. American Family Physician 2008; 77: 1139-40.

6. Dölekoğlu S. Physiological changes in pregnancy and their importance for dentistry. 7tepe Klinik 2011;3: 55-61.

7. Offenbacher S, Katz V, Fertik G, Collins J, Boyd D, Maynor G, McKaig R, Beck J. Periodontal infection as a possible risk factor for preterm low birth weight. J Periodontol 1996; 67: 1103-13.

8. Jeffcoat MK, Geurs NC, Reddy MS, Cliver SP, Goldenberg RL, Hauth JC. Periodontal infection and preterm birth: results of a prospective study. J Am Dent Assoc 2001;132:875-80.

9. Ceylantekin Y, Alikaya C, Köken GN. Oral and dental hygienic evaluation of prematüre birth. J Gynecol Obst 2011; 21: 184-9.

10. Dellinger TM, Livingston HM. Pregnancy: Physiologic changes andconsiderations for dental patients. Dent Clin N Am 2006; 50: 677-97. 
11. Jazarzadeh $H$, Sanatkhani M, Mohtasham N. Oral pyogenic granuloma: A review. J Oral Scien 2006; 48:167-75.

12. Kandan PM, Menaga V, Kumar RR. Oral health in pregnancy (Guidelines to gynaecologists, general physicians \& oral health care providers). J Pak Med Assoc. 2011; 61: 1009-14.

13. Nethravathi TD, Venugopal S, Joshipura V. Florid granulation tissue/pregnancy tumor case report. J Dent Sci Res 2010;1: 51-6.

14. Hartzell, M. B. Granuloma pyogenicum (botryomycosis of French authors). J Cutan Dis 1904;22: 520-3.

15. Martins-Filho PRS, Piva MR, Ferreira da Silva LC, Reinheimer DM, Santos Ts. Aggressive pregnancy tumor (pyogenic granuloma) with extensive alveolar bone loss mimicking a malignant tumor: case report and review of literature. Int. J. Morphol 2011;29: 164-7.

16. Ege $B$, Demirkol $M$, Keskinrüzgar $A$, Aras $M H$. Palatinal yerleşimli oral pyojenik granüloma: Olgu sunumu. Atatürk Üniv. Diş Hek. Fak. Derg. 2013; Supple 7: 20-3.

17. Powell JL, Bailey CL, Coopland AT, Otis CN, Frank JL, Meyer I. Nd: YAG laser excision of a giant gingival pyogenic granuloma of pregnancy. Lasers Surg Medici. 1994; 14: 178-83.

18. Bodur S, Özcan E, Gün İ. Periodontological disease of pregnancy: pregnant tumor. Perinatol Derg 2010;18: 55-8.

19. Yadav N, Pahwa P, Lamba AK, Faraz F, Tandon S. $\mathrm{Er}, \mathrm{Cr}$; YSGG laser-assited excision of pregnancy tumor. J Oral Laser Applicat. 2010;10;171-4.

20. Raber-Durlacher JE, Van Stenbergen TJ, Vander Velder U, Graaff J, Abraham-Inpijn L. Experimental gingivitis during pregnancy and post-partum: clinical, endocrinological, and microbiological aspects. .J Clin Periodontol 1994;21:549-58.

21. Adriaens LM, Alessandri R, Spörri S, Lang NP, Persson GR. Does pregnancy have an impact on the subgingival microbiota? J Periodontol 2009;80:72-81.

22. Carrillo-de-Albornoz A, Figuero E, Herrera D, Bascones-Martı'nez A. Gingival changes during pregnancy: II. Influence of hormonal variations on the subgingival biofilm. J Clin Periodontol 2010;37: $230-40$.

\section{Yazışma Adresi}

Gülser Kılınç

Dokuz Eylul University

School Of Medicine,

Pedodontia Clinic

Tel: 00902324122181

e-mail: gulser.kilinc@deu.edu.tr 